\title{
Making Australian Food History
}

\author{
Colin Bannerman
}

The importance that food and eating have assumed as components of popular culture in Australia has not yet been matched by thorough historical analysis. This essay briefly surveys existing histories of non-indigenous eating in Australia and outlines a theoretical framework within which an explanatory history of Australian food culture could be constructed. It suggests that, for reasons of relative newness and isolation, the Australian setting is ideal for testing such a framework. Finally, it notes that the processes of communication through which an Australian culture of food and eating developed - whether or not that culture amounts to a distinctive cuisine-largely documented its progress, thus simplifying the task for historians.

\section{Food and eating in popular culture}

In the past two centuries there has been a dramatic change in the role of food and eating in Australian public consciousness. Examination of early colonial newspapers, beginning with the Sydney Gazette and New South Wales Advertiser (first published 1803), suggests a society in which food was regarded primarily as sustenance. Public discussion of food was largely confined to matters of supply, distribution and price. There was no gastronomic discourse, no mention of food fashions, no trade in recipes. Towards the end of the nineteenth century some newspapers were offering regular columns of advice on housekeeping topics, including menu planning and recipes. However, eating remained essentially a private activity, even when undertaken in company (Bannerman, Print Media 36ff). Public dinners or gala social events were often 'noticed' in the newspapers as matters of general interest, but journalists confined their reports to questions such as who was present, what they wore and what speeches were made. Rarely was food mentioned in any more than the most general and cursory terms, such as 'the Company assembled sat down to a splendid dinner' (Sydney Gazette, 6 June 1812: 3).

By the late twentieth century, food and eating had become prominent public preoccupations. Evidence of this dramatic cultural revaluation abounds. In bookstores, for example, cookery and all things related to it are often among the larger displays. Recipe books and instruction manuals are only the core of an expanding genre of literature in which gastro-porn, gastro-humour, gastro-travel, biography, fiction and how-to-save-the-planet are already well represented. 
There are specialty stores selling all manner of cookware, tableware and other paraphernalia associated with food, eating and drinking. The commodification of food culture (as distinct from foodstuffs) has progressed to the point where 'reality' television shows about cooking seem to have out-ranked shows about randy moderns sharing house. ${ }^{1}$

Perhaps most telling is the extension of the phenomenon of mass media celebrity to include culinary personalities. A few nineteenth and early twentieth century chefs such as Louis Ude, Charles Francatelli, Alexis Soyer and Auguste Escoffier achieved considerable fame and even in the antipodes were venerated among connoisseurs of food and cooking. For example, an outstanding cook might be an 'Australian Soyer' ('Ballarat and Creswick Spring Races') or a 'veritable Francatelli' ('Cooks I have known'). Melbourne had a Francatelli Café in Collins Street ('Visitors to Melbourne'). But such celebrity hardly compares with that achieved by late twentieth century gurus Jamie Oliver, Nigella Lawson and others who have been vigorously promoted as a new kind of culinary commodity. The success of the personality commodification strategy is illustrated by a 2010 report in the Sydney Morning Herald ('SNAGS'):

The Cleo Bachelor of the Year competition has turned its back on NRL players, with a move towards foodies, musos and creative men.

It's believed to be the first time in the magazine competition's 24-year history that a rugby league player hasn't been included in the top 50 finalists.

Instead, foodies like patissier Adriano Zumbo, celebrity chef Curtis Stone and food photographer and chef Luke Burgess seem to be the flavour of the day.

Scholars, too, have jumped on the commodification bandwagon. At the beginning of the twentieth century, when cooking and eating were still relative newcomers to the public discourse made possible by a rapidly expanding newspaper industry, Melbourne journalist 'Rita' Vaile dreamt of a day when Australia would have a 'Chair of Gastronomy' and took a faltering step towards it by lending her weight to the establishment of the short-lived Australian Institute of Domestic Economy (Bannerman, Print Media 276ff; 'Rita'; Docherty 8). Now degrees in gastronomy seem set to emulate the MBA phenomenon of the 1980s and food has become a respectable subject for investigation with philosophers, sociologists, historians, cultural theorists, ecologists and many others all having a go at it.

1 Masterchef Australia, Channel 10, 2009 and 2010; My Kitchen Rules, Channel 7, 2010 and 2011. 
However, while there is general acceptance that the transformation of food from a practical necessity not generally discussed in polite company to a dominating theme of public discourse has been rapid and dramatic, there is less agreement on how it happened. And, surprisingly, the question seems to have held little fascination for most historians. For the best part of two centuries they have managed to write their accounts of colonisation and nationhood with only scant reference to how the settlers and their descendants fed themselves. And even some fairly recent general histories, such as Geoffrey Blainey's Shorter History of Australia, fail my version of the f-test, displaying index entries for 'football', but not for 'food'. Thorough investigation of the history of food and eating can help to illuminate the development of Australian society and, more generally, processes of cultural change.

\section{Historiography}

Probably the first attempt at a formal history of food and eating was by Anne Gollan in 1978. Despite her disclaimer (vii) that it was 'not a comprehensive history' - and, indeed, her approach was more nostalgic than analytical-The Tradition of Australian Cooking was a useful descriptive account beginning with a brief survey of the foodways of indigenous peoples and tailing off in the decades of rapid change following World War II.

Gollan divided her account into three phases: 'the outdoor kitchen' (indigenous foodways, campfire cookery); 'the outhouse kitchen' (pioneer cookery, gadgets and refinements); and 'the respectable kitchen' (gas cooking, the indoor kitchen and the kitchen as a public room). The changing character of the kitchen served as a useful metaphor for the imposition on Australia of Victorian ideals of civilisation and progress. These phases were not strictly chronological, but loosely defined and overlapping stages of development: survival and discovery (before c. 1870); awareness and refinement (c. 1850 to c. 1920); and convenience and commercialism (c. 1880 onwards).

Consistent with the kitchen metaphor, she illustrated her book lavishly with recipes, encouraging readers to trace the parallel histories of kitchen and cooking (and, by extension, eating). The narrative itself was brief, taking less than half the book. Gollan was well aware (23) that diet is determined by what is available and practicable, anticipating Michael Symons's discovery in 1982 that Australians had enjoyed 'one continuous picnic' (discussed below). A weakness of her account stems from her assertion that 'it would be impossible in a book of this size to trace the foreign influences on Australian food' (92, 
193). Such 'foreign' (presumably non-British) influences have turned out to be quite significant, and were evident enough even in the early recipe record (Bannerman, Print Media), yet she gave them only cursory attention.

Anne Gollan discerned in the history of food and cooking in Australia two seemingly contradictory trends (192). One was the dehumanising of food rituals under the influence first, of the necessities of survival among white settlers and second, under the onslaught of commercialism. The other was a re-humanising process that liberated cooks from drudgery and lifted Australians out of the monotony of meat, flour, tea and sugar. She concluded that 'Australians in the kitchen find themselves at something of a crossroads' between fashion and convenience on the one hand and 'the natural lifestyle' on the other (195-6). With the benefit of hindsight one might now contend that the crossroads at the end of the 1970s offered three main paths: 'convenience', 'gourmet' and 'natural' (now better known as 'organic'). All were fashionable and, in varying degrees, commercialised.

The most controversial and, arguably, influential history of food and eating in Australia has been Michael Symons's One Continuous Picnic (1982) which, thanks to a combination of vigorous promotion and provocative thesis, quickly captured the imagination of foodies. Symons had 'set out to write, as a journalist, about Australian food', apparently in an attempt to explain why Australia suffered 'the world's worst cuisine' ('Potted History' 64; One Continuous Picnic 254). His efforts convinced him of 'the importance of the historical process in determining feeding' and 'even more of the power of gastronomy in understanding the world' ('Potted History' 64). The resulting book was history driven by an underlying gastronomic mission. This duality - and the brashness of some of his claimshelped to popularise the book, but ultimately limited its usefulness as history (see, for example, Pont 'Upstart Gastronomy'; Kingston).

Symons's central thesis was that the world's best cuisines were founded on a tradition of peasantry engaged in intensive agriculture and that Australia never had such a tradition, but moved abruptly from one of hunting and gathering to a purely industrial system of mechanical farming, processing, transporting, marketing and consuming (Preface and 12). Without a 'true contract with the land', as the dust-cover blurb said, food and eating patterns were founded on considerations of portability and profitability rather than self-sufficiency. Australians in general have therefore failed to develop a taste for fine food and cooking.

Like Anne Gollan, Michael Symons also found three stages of culinary development, but used them to describe a process by which he said Australians became alienated from the sources of their food. First (from 1788 to the 1860s), the growing of food, animal and plant, was industrialised by the implantation 
of modern methods of production based on specialisation and economies of scale. In terms of feeding it was the era of bush rations; the dominant form of transport was the sailing ship. Then the processing and retailing of food were industrialised as mass systems of transport, storage and distribution developed to gather, rationalise and sell durable produce to city households and overseas markets. This was the era of tinned and processed food, and of railways (1850s to 1930s). Finally, cooking was industrialised as factories and restaurants took over most of the work of preparing food for table (and Gollan's 'respectable kitchen' became a small nook for final assembly and dishing-up). This was the era of convenience foods and of automobiles (1940s onwards).

Symons's identification - no doubt inspired by Geoffrey Blainey (The Tyranny of Distance, 1966) — of distance and transport as important factors in Australia's feeding history was a useful contribution, and the work generally remains a good reference on various events and stages in Australian culinary history. However, his preoccupation with 'understanding why Australian society seemed culturally impoverished' (preface) probably focussed his inquiries in areas relevant to gastronomic judgements already made at the expense of a broader examination of factors influencing the construction of a local culture of food and eating.

Symons concluded his work by offering readers much the same choice as had Anne Gollan: 'Good food has never come from factory farms, process lines, canteens, supermarkets and fastfood [sic] chains. It still belongs to careful vegetable gardeners, painstaking cheese-makers and dedicated chef-patrons, meeting in the bustling market-place' (One Continuous Picnic 262).

After Symons, interest in writing a general history of cuisine in Australia seemed to wane. Richard Beckett's Convicted Tastes (1984) was not a scholarly work and was apparently not intended for critical reading or close analysis. It was primarily a critique of patterns and styles of eating from about the time of colonisation to the early 1980s, with little to offer by way of explanation. Despite the publisher's blurb on the dust-cover that the work 'proves beyond doubt that the food of Australia is much more than simply an extended version of 'Waltzing Matilda', and occasional disclaimers (for example, page 3), Beckett's contention, consistent with the title, was that Australia had never really recovered from the contempt for food bred into its people in the harsh environment of the early years of European settlement.

In a more recent work, When Mabel Laid the Table, Warren Fahey (2002) offered 'a social history of eating and drinking in Australia [which] shows that we in fact have a unique tradition of wining and dining, Australian style, that started expressing itself from the very early colonial days and has never stopped' (vii). 
However, it was essentially an ordered collection of folklore, tales, verse and recipes, with an emphasis on the curious, interesting and nostalgic. It serves to entertain rather than to educate or explain.

The few other monographs in the field made more specialised contributions. They included Frederick Clements (1986) on nutrition; Gordon Pickhaver (1986) on cheese in South Australia; Barbara Santich (1995) on dietary advice; Angela Heuzenroeder (1999) on the food of Prussian migrants to the Barossa Valley; Keith Farrer (1980) on food technology in the nineteenth century and (2005) on food science and technology; and my own work (1996) on cookery around the time of federation and (2008) on fashion and fad in Australian cuisine. Journal articles, by their nature, are more limited still. We are thus left with One Continuous Picnic as the dominant historical account of eating in Australia.

Graham Pont (Review) was highly critical of One Continuous Picnic, arguing that there is no logical or necessary connection between Symons's two premises (that great cuisines are founded on a tradition of peasantry and that the colonial economy produced a 'uniquely "pure" industrial cuisine'). According to Pont, it is far from clear that a peasant tradition is either necessary or sufficient for the development of a great cuisine. He contended that 'the character of Australian food is neither peasant nor aristocratic - it is almost entirely the product of a cuisine bourgeoise' and that the argument about a peasant contribution is therefore largely irrelevant. 'The peasants who are most significant in the history of Australian food are those who arrived from the Mediterranean countries after the Second World War' (47-8). Pont also disputed the significance of Symons's second premise as an explanation for Australia's bad eating, arguing that he had 'by no means shown the impossibility of creating something like a traditional fine cuisine in the modern [industrial] context' (42). In short, Symons's analysis owed more to gastronomic romanticism than to history.

\section{How cuisines are made}

Leaving aside the question of why Australia failed to produce what he considered to be a satisfactory cuisine, at a more general level Symons left largely unexplained the processes by which Australian cuisine - good or bad-was made. Yet the development of a culture of food and eating among 'migrants' to Australia since 1788 would be an ideal setting for a study of the processes of cuisine-making. The newcomers neither found a greenfield site - since the original inhabitants already had a highly developed food culture that was uniquely adapted to the environment (see, for example, Isaacs) - nor quite succeeded in behaving as though they had, since they continued to exploit those local food resources suited to their European tastes long after the hungry years. The first Australian 
cookery book writer (Abbott) catalogued some of these native resources; a few decades later so did Mina Rawson, who famously remarked that 'whatever the blacks eat the whites may safely try' (Rawson 54). Nevertheless, the foodways of the hunter-gatherer inhabitants were radically different from those of the semiindustrialised incomers, who constructed a cuisine in which local and imported components were not too difficult to separate. The first fleet brought its own printing press - though it was some seven years before it could be put to use and fifteen before the colony's first newspaper appeared. The novelty of the colonial enterprise - and therefore its newsworthiness back home - guaranteed that literate colonists would record their experiences and that a good proportion of their records would be preserved. The very newness of the cuisine meant that all its important stages were documented. This documentation is now a rich source of data from which a communication-based model of food culture can be constructed.

The seeds of a general theory of the making of a cuisine were offered by Michael Freeman in his 1977 essay on Sung cuisine in China. Freeman suggested that the appearance of a (presumably superior) cuisine requires first, a wealth of local and imported ingredients and second, 'a sizeable corps of critical, adventuresome eaters, not bound by the tastes of their native region and willing to try unfamiliar food' (144). He emphasised that this elite corps must be a large one. 'An individual ruler or a tiny elite may command superlative cooking, but cannot create a cuisine. The eaters must also be sophisticated enough to encourage culinary adventures' and their attitudes should 'give first place to the real pleasure of consuming food rather than to its purely ritualistic significance' (145).

Jack Goody, in Cooking, Cuisine and Class (1982), examined the relationship between stratified cuisine and stratified society in a wider context. With no apparent gastronomic agenda, he started from a position that one needs 'first, to analyse cooking in the context of the total process of production, preparation and consumption of food, and, [second], to set this analysis within a comparative perspective' (2). Following Freeman, Goody noted that 'a salient feature of the culinary cultures of the major societies of Europe and Asia is their association with hierarchical man [sic]' (99). Differentiated cuisines emerge from differentiated societies: it is only the upper class of society that possesses the resources and disposition to sponsor the development of high-class cuisine (Pont, Review 226). Stephen Mennell reached similar conclusions in his comparative study of French and English cuisine (All Manners of Food).

Symons's book more or less coincided with the appearance of Jack Goody's. Symons was aware of Freeman's work, but-perhaps out of gastronomic romanticism - regarded the agricultural labours of peasantry as indispensable. 'So far, great cuisines have arisen from peasant societies, even if recognised by 
elites and refined by professionals' (One Continuous Picnic 12) was about as far as he was prepared to go. For him, the gastronomic endeavours of an adventuresome elite were not sufficient to guarantee the emergence of a great cuisine because, presumably, the elite necessarily constructed their pleasures from the products of peasants. This left little room for a great cuisine ever to be founded on, for example, trade or industry. Symons's position was the more puzzling because colonial Australia was rather better supplied with farming peasants than with resourceful elites; it would have made more sense to lay the blame for Australia's bad cooking at the feet of an absent aristocracy than an absent peasantry.

Freeman, Symons, Goody and Mennell were all concerned with stratified cuisines: what are the conditions necessary for a high-class cuisine to develop within a society where the presumed norm is merely ordinary? However, stratification in a cuisine is necessarily a secondary development. As I have suggested above, the first question for historians to ask is not why Australians failed to develop a world-class cuisine, but how they made the one they didand popular narratives, largely based on themes of British colonialism modified by subsequent immigration and industrialisation, hardly answer.

In commenting on Symons's peasant thesis, Pont sharpened Goody's thus: 'stratified cuisines depend on two conditions, the pen and the plough. The high cuisines of the past were formed by the plough but codified by the pen; gastronomy presupposes literacy, for so long the exclusive prerogative of a small, educated elite' ('Upstart Gastronomy' 47). Though an oversimplification of the process of cuisine making (since it omits, for example, diversity of ingredients, the means to acquire them and the drive to create display), Pont's formulation helped to redress an imbalance in One Continuous Picnic by pointing out that the role of the elite was not merely as consumer of peasant labour, but as active participant in the construction of a cuisine. Moreover, it suggests the possibility of a more general theory of how cuisines are made.

A conceptual framework used by Jack Goody in his comparative studies (37) provides a useful starting-point for thinking about systems of providing and transforming food:

$\begin{array}{lll}\text { Processes } & \text { Phases } & \text { Locus } \\ \text { Growing } & \text { Production } & \text { Farm } \\ \text { Allocating/storing } & \text { Distribution } & \text { Granary/market } \\ \text { Cooking } & \text { Preparation } & \text { Kitchen } \\ \text { Eating } & \text { Consumption } & \text { Table } \\ \text { Clearing up } & \text { Disposal } & \text { Scullery }\end{array}$

The model is capable of being elaborated or simplified as required. For example, in some social settings the disposal phase is unimportant, if present at all. 
The production phase can be understood to include, at one extreme, hunting and gathering and, at the other, the manufacture of food from materials which may never enter the diet in their natural states - the peasants' harvest is thus only one of a range of possibilities. The distribution system can be as simple as a tradition of barter among neighbours or as complex as a multi-layered network of local, regional and global commercial enterprises. A notable consequence of industrialisation, as many foodies have lamented, has been a shift of much of the process of cooking from home kitchen to factory or restaurant.

The whole system can be thought of as a food culture. I prefer the term 'food culture' to 'cuisine' here for two reasons. First, 'cuisine' can easily be a source of confusion, since it is variously used to refer to a body of cookery, a particular style (as in Mennell's study of French and English) or to a gastronomic or aesthetic judgement (as when it is used to distinguish 'high class' from 'low class' cookery). Sometimes, especially in the popular press, it distinguishes restaurant food from home cooking; confusion arises when generalised pronouncements about 'Australian cuisine' are made on the basis of a sample of restaurant meals but understood by readers in the context of the food of everyday experience. Second, food culture means something more than cuisine, which on most understandings is concerned primarily with kitchen and table rather than with farm, granary or even scullery.

It is not necessary to assume that a 'nation' must have a unified food culture, much less a 'national cuisine'. Nor should stratification from 'low' to 'high' necessarily be considered the most important differentiation. A society can differentiate its cuisine along as many dimensions as are important to it. In a multi-cultural environment there are likely to be several-perhaps manydistinctive 'ethnic cuisines'. In old, geographically diverse cultures regional differentiation of cuisine is common. The fairly recent emergence-and commodification - of regional food specialties in some parts of Australia (for example, King Island and Margaret River) hardly suggests that we may yet see significant regional differentiation of the cuisine. However, Alison James has suggested a framework within which it is theoretically possible.

Following work by Ulf Hannerz on 'cosmopolitans and locals in world culture', James identified four contemporary food trends that she described as forming overlapping discourses. The first concerns global food and emphasises the increasingly transnational character of food, in which 'foodstuffs are seen to have an international, increasingly homogeneous, character' (82). The second relates to expatriate food and is characterised by 'an urgent emphasizing of the heterogeneity of cuisines, of their cultural diversity, of the fine distinctiveness of particular local food stuffs and of the peculiar and special experience of eating food within its own locale'. The third, food nostalgia, 'vociferously defends the local [and] is truly anti-cosmopolitan'. Finally, there is a discourse 
concerning food creolization which accepts, even promotes, the mixing of cuisines. Along with an enthusiasm for East-West fusion, it leads to creations such as lasagne with chips and vegetarian haggis. On her analysis, the end point of global commodification of food resources and food culture is not necessarily homogenisation; sub-cultures may interact with the dominant culture or cuisine without necessarily being absorbed by it. A food culture remains a lively and complex negotiation in which the central or inclusive and the peripheral or specific figure along with innovation, authenticity and other forces for or against change.

In a more general theory, then, Jack Goody's stratification is replaced by multi-dimensional differentiation, Graham Pont's pen is replaced by the communication technologies of the age and Michael Symons's peasant harvest is replaced by whatever food resources are available, whether gathered in the wild, home-grown, artisanal or industrial. (And industrialists can, if they set their minds to it, produce to high standards of gastronomy-gourmet critics should generally be directing their ire to the compromises of consumerism rather than to industrialisation per se.) The axiom that people tend to eat what is available to them allows for ever-changing perceptions of availability, including considerations such as price and convenience, and influences from various sources such as peer-groups, advertisers, opinion leaders and policy makers. As others have pointed out, construction of a cuisine is not just a gastronomic project, but takes place within a complex of individual and social activities. A history of eating in Australia would therefore need to be informed by a general understanding of how a food culture evolves within a society and within that, how component cuisines are constructed.

Food culture is the ensemble of shared knowledge, attitudes and practices that people bring to selecting, preparing and eating food. It exhibits in some degree order, symbolism and continuity. Most important, it is a product of interactions among people and is therefore created, shaped and sustained through communication. Following Goody's model, one can expect to read within a food culture the history of a social group exploring, appropriating, exploiting, adapting and supplementing its natural food resources; developing ways to harvest, process, store and distribute its food; negotiating through experimentation and information exchange agreed ways to prepare, present and consume its food; investing food choices and methods with meanings; storing the knowledge of resources, methods and meanings in collective memory; developing ways to preserve, adapt and access collective knowledge, and so on. Food cultures of the distant past can be read, if only dimly, in the archaeological and other evidence they may have left behind. In societies where literacy is not well advanced, the collective knowledge can be accessed and recorded by anthropologists. Modern societies not only create records-written, 
pictorial, auditory and physical, all of varying permanency - of their collective knowledge, but conduct much of the discourse of cultural construction through communication media that also create historical records. The challenge for the student of modern food cultures is generally not to find enough evidence, but to select from the great volume of it.

\section{Emergence of food culture in Australia}

The process of making a food culture in colonial Australia is remarkably well documented even in the pages of its first newspaper, the Sydney Gazette. From the first issues (1803) it recorded the legal and administrative steps taken to secure, regulate and expand the food supply. Through the market reports, shipping notices and advertisements it documented the transition of food from necessity of life to commodity and the establishment of a culture of commercialism. The proportion of space allocated to food provides some (albeit imperfect) measure of the perceived importance of food at any time. As the century progressed new papers took up the story, documenting the emergence of cooking and eating as cultural activities. The newspaper record was supplemented by other print media, especially magazines and cookery books.

Much of my work on Australian food history has been concerned with charting the emergence of food and eating into public consciousness through the record of these media (Bannerman, Print Media, 'Recipes come from Kitchens'). I have found within them a discourse in which information about various aspects of feeding was gathered from local and overseas sources and circulated for instruction, entertainment and use. The discourse and the means of conducting it were products of their age. Public participation was evident in the correspondence columns of weekly newspapers and in community cookery books. The discourse drew on various themes that were prominent in other Western discourses and reflected social and moral values of the times. It evidenced beliefs that the manner of a society's feeding demonstrates the extent of its civilisation and that refinement of food and feeding contributes to the improvement of society. It also reflected nationalist sentiment and demonstrated some attempts to develop a distinctive Australian cuisine.

On my reading of the record, the foundation of the cuisine was not the British foodways imported by the early settlers, but the English language. The more recent rise of popular interest in 'gourmet' food and cuisines of the ethnic 'other' were not, on the whole, products of post-war migration but reflected a worldwide movement. They are better explained as outcomes of the cosmopolitanlocal dialogue described by Hannerz and James than by tourism or population movements. 
The printed record shows not only the discourse through which cuisine was created and maintained, but also that through which it was evaluated. There was general agreement that considerable improvement was needed and again, communication was the key to improvement. The reformers used print media to arouse public interest, to express indignation, to foster understanding by circulating information on overseas practice and ideas for local action, and to encourage enthusiasm by holding up the prospect of a brighter culinary future. The record illustrates the emerging role of the education system in shaping cuisine, the influence of popular attitudes towards science on thinking about cookery, and the early influences of commercialisation and industrialisation. In the day-to-day record of recipes, food journalism and newspaper correspondence columns there was evidence of food culture as both an expression of conceptions of character and identity and a formative influence on them.

I found that the engine of cultural change has been industrial progress and that the communication system that supports and enriches food culture may also tend to undermine it in various ways. Goody noted that the advent of printing had enabled the growing bourgeoisie of early eighteenth century England to develop a taste for French cuisine, previously the province of the aristocracy (147-8). He attributed to J.D. Vehling in 1936 the observation that a feature of the 'avalanche' of cookery literature that started with Platina about 1474 was the access it opened up to the culinary property of the aristocracy: English gastronomic literature of the three centuries preceding the First Fleet is crowded with 'closets opened', 'secrets let out' and 'other alluring titles purporting to regale the prospective reader in profitable and appetizing secrets of all sorts'. Kitchen secrets became commercial articles. And, Goody added, 'becoming a commercial article at the hands of the printer could entail impoverishment'.

In the Australian setting impoverishment was of three main kinds. First, the adoption of print by individuals and groups as a medium of self-expression enabled the rapid development of a conscious popular culture that has tended to undermine the culinary authorities by adapting, appropriating or even misinterpreting standard recipes and procedures. (However, in recent decades, post-modernism, the internet and commodification of hero-chefs have so changed the roles of culinary authority and self-expression that the extent of undermining may be difficult to determine.) Second, although the use of communication media to turn food culture into an array of commercial products has brought great benefits to the masses, it has also attracted much critical comment from gastronomes and nutritionists. Third, the print media ensured that Australian food culture developed in dialogue with that of other countries. The tendency to import experience and wisdom and to measure Australian cultural achievements by those of the Old World paved the way for 
the internationalising of the cuisine in the second half of the twentieth century. Arguably, the quest for a convincing expression of Australian national identity in its food and eating, if it ever existed, was lost.

Whether or not Australia ever develops a 'national cuisine' or becomes a tourist destination for gourmet travellers, it can host profitable enquiry into how cuisines are made. And the richness of documentation not only facilitates such a study, but to the extent that culture is an outcome of communication, largely answers the question.

Colin Bannerman, after several decades as a senior bureaucrat in Canberra, took up a post as Senior Research Fellow at the University of Canberra in the field of educational communication, then turned to independent scholarship. His publications include A Friend in the Kitchen: Old Australian Cookery Books (1996); Acquired Tastes: Celebrating Australia's Culinary History (1998); Seed Cakes \& Honey Prawns: Fashion and Fad in Australian Food (2008) and various journal articles. His doctoral thesis was on the role of print media in the development of Australian food culture. He is currently working on a book that will explore the processes through which cuisines are constructed. He believes that Australia, as a relatively new cuisine to emerge from readily identifiable roots and in an environment that has been richly documented, is an ideal locus for such a study.

\section{Works cited}

Abbott, Edward ('an Australian Aristologist'). The English and Australian Cookery Book: Cookery for the Many, as well as for the 'Upper Ten Thousand'. London: Sampson Low, Son, and Marston, 1864.

'Ballarat and Creswick Spring Races'. Ballarat Star, 3 December 1857: 1.

Bannerman, Colin. A Friend in the Kitchen: Old Australian Cookery Books. Sydney: Kangaroo Press, 1996.

- Print Media and the Development of an Australian Culture of Food and Eating c. 1850 to c. 1920: the Evidence from Newspapers, Periodical Journals and Cookery Literature. Ph.D. Thesis, University of Canberra, 2001.

-. 'Recipes Come from Kitchens: Food Cultures Come from Printing Presses'. Culinary History. Ed. A Lynn Martin and Barbara Santich. Brompton (SA), East Street Publications, 2004. 107-114.

- Seed Cake \& Honey Prawns: Fashion and Fad in Australian Food. Canberra: National Library of Australia, 2008. 
Blainey, Geoffrey The Tyranny of Distance: How Distance Shaped Australia's History. Melbourne: Sun Books, 1966.

-. [1994] A Shorter History of Australia. Milson's Point (NSW): Random House Australia, 2000.

Clements, Frederick W. A History of Human Nutrition in Australia. Melbourne: Longman Cheshire, 1986.

'Cooks I have known.' Town and Country Journal (Sydney), 12 June 1899: 14.

Docherty, James. 'The Emily Mac': The Story of the Emily McPherson College 1906-1979. Melbourne: Ormond Book \& Educational Supplies, 1981.

Fahey, Warren. When Mabel Laid the Table: The Folklore of Eating and Drinking in Australia. Sydney: State Library of NSW Press, 2002.

Farrer, K.H.T. A Settlement Amply Supplied: Food Technology in Nineteenth Century Australia. Melbourne: Melbourne UP, 1980.

-. To Feed a Nation: A History of Australian Food Science and Technology. Collingwood (Vic.): CSIRO Publishing, 2005.

'Gastronomy.' Wikipedia. <http://en.wikipedia.org/wiki/Gastronomy > Accessed 15 April 2010.

Gollan, Anne. The Tradition of Australian Cooking. Canberra: Australian National University Press, 1978.

Goody, Jack. Cooking, Cuisine and Class: A Study in Comparative Sociology. Cambridge UP, 1982.

Hannerz, U. 'Cosmopolitans and Locals in World Culture'. Theory, Culture and Society 7.2-3 (1990): 237-251.

Heuzenroeder, Angela. Barossa Food. Kent Town (SA): Wakefield Press, 1999.

Isaacs, Jennifer. Bush Food: Aboriginal Food and Herbal Medicine. Willoughby (NSW): Weldon Publishers, 1987.

James, Alison. 'Cooking the Books: Global or Local Identities in Contemporary British Food Cultures?' Cross-Cultural Consumption: Global Markets, Local Realities. Ed. David Howes. London: Routledge, 1996. 77-92.

Kingston, Beverley. 'When did we Teach our Girls to Cook?' Australian Cultural History 15 'Food, Diet Pleasure' (1996): 89-101. 
Mennell, Stephen. All Manners of Food: Eating and Taste in England and France from the Middle Ages to the Present. 2nd ed. Chicago: U of Illinois P, 1996.

Pickhaver, Gordon S. (with James Dez. Marshall). People, Places and Cheese in South Australia 1842-1984. Adelaide: Dairy Industry Authority of Australia, 1986.

Pont, Graham. Review of Goody op. cit.Mankind 14.3 (1984): 225-226.

-. 'Upstart Gastronomy: A cuisine without peasants.' Proceedings of the Third Symposium of Australian Gastronomy, 'A Multiculinary Society'. Ed. Barbara Santich and Michael Symons. Adelaide: 1988. 41-55.

Rawson, Mrs Lance [Mina]. The Antipodean Cookery Book and Kitchen Companion. Melbourne: George Robertson, 1907.

'Rita'. 'Cottage Cookery'. The Herald (Melbourne), 18 September 1897: 3.

Santich, Barbara. What the Doctors Ordered: 150 Years of Dietary Advice in Australia. South Melbourne: Hyland House Publishers, 1995.

Sydney Gazette and New South Wales Advertiser. Sydney, 5 March 1803, foll.

'SNAGS in league of their own in bachelor contest.' The Age, 15 March 2010. $<$ http://www.theage.com.au/lifestyle/celebrity/snags-in-league-of-theirown-in-bachelor-contest-20100315-q7fk.html> Accessed 16 March 2010.

Symons, Michael. One Continuous Picnic: A History of Eating in Australia. Adelaide: Duck Press, 1982.

-. 'A Potted History of Australian Gastronomy.' First Symposium of Australian Gastronomy: The Upstart Cuisine (Proceedings). Ed. Barbara Santich. Adelaide, 1984. 57-67.

'Visitors to Melbourne dine at Cafe Francatelli...' (advertisement). Table Talk. Melbourne, 26 February, 1914: 13. 